\title{
Transformative school initiatives through the use of digital technologies in Kosovo during Covid-19
}

\author{
Dr. Arlinda Beka, University of Prishtina “Hasan Prishtina”, Kosovo, arlinda.beka@uni-pr.edu \\ ORCID ID: 0000-0002-9871-783X
}

\begin{abstract}
The school closure during the COVID-19 pandemic is one of the biggest challenges of the last two decades, forcing the country to mobilize quickly and transform the teaching and learning process from regular to virtual/online classes.

Purpose of this research was to gather data from school teachers and principals regarding online learning, its management, and the challenges they faced during the COVID-19 transformation of education.

This research was conducted using a mixed-method. The research was conducted with teachers and principals of the pre-university system (grades 1 st to 12 th).

The research findings will serve policymakers, schools, and all relevant stakeholders involved in the country's educational system when planning reforms and improvements in education.
\end{abstract}

Keywords: Schools, Transformation, Digital Technology, Teaching, Online learning, Kosovo, Covid-19. Received: 21.07.2020 Accepted: 14.12.2020 $\quad$ Published: 10.01.2021

\section{INTRODUCTION}

Digital transformations are changing economies and societies around the world. These transformations bring both opportunities and challenges depending mainly on their population's skills and preparedness to change. (OECD, 2019).

Societies should be ready for continuous changes. It is essential to follow the contemporary trends of digitalization and ICT usage in every segment of life, disseminating information and knowledge to a broader audience (B.Beka \& A. Beka, 2017). The necessity of following digital trends and digital advancement has proven to be very important for societies, especially in the education area. Obtaining digital skills was proven right, especially during the Covid-19 Pandemic when many countries decided to close schools and start online learning. Digitization creates a new and entirely interconnected world that necessitates and enables utterly original understandings, approaches, and arrangements aspirations (M. Douse and Ph. Uys, 2020). The expansion of ICT in contemporary society has changed communication and social interaction worldwide (Välimaa J., Papatsiba V., Hoffman D.M., 2016). The introduction of ICT into modern society has changed communication and behavior and influenced human relations in social and corporate environments (Bandura, 2001).

In the last decades, ICT is considered crucial for the education system, and every school or university was seeking its integration within their curricula (Tallvid, 2016). However, not all countries have managed to have full ICT integration in their education systems for different reasons. ICT integration in education directly impacts the quality assurance and improvement of teaching and learning, thus helping teachers and students get the best out of education. Ham et al. have identified the following indicators of the ICT integration in education:

"ICT integration in education systems brings changes in teachers' perceptions and understandings about ICT in education. ICT integration in education certainly impacts and improves teacher competence with ICTs, increased teacher confidence about integrating ICTs into classroom activities, and increased classroom usage of ICTs" (V. Ham et al., 2002). Bases for the integration of computerized innovations incorporate: improving guidelines, expanding professional significance, contributing to knowledge-based economies, improving learning encounters, changing the instructional method to create it more student-centered, constructivist in nature, and with a center on higher-order learning, and encouraging personalized learning" (Ch. N. Blundell, et al., 2016).

Multiple challenges follow those changes. These challenges have created considerable demands for schools regarding developing strategies to support the digital competencies needed for providing high-quality teaching and learning (Pettersson, 2018). However, integrating technology into the curriculum of the classroom is becoming an inseparable part of good teaching (Beka A. , 2014). 
ICT integration in curriculums helps the development of learning competencies. When it comes to digital competences in teaching and learning, according to Orlando (2014), there are:

"Four categories of change in their practices:

(1) Changes in knowledge, which is shifts in teachers' knowledge of digital technology as a learning resource,

(2) Changes in a learning organization, which are new processes the teachers introduce to support the development of their practice with technology,

(3) Changes in teaching practices, which are new teaching strategies, curriculum content, classroom organization, and use of resources teachers introduce into their practices with technology,

(4) Changes in core approach, which are fundamental changes to the way teachers understand the process of learning" (Orlando, 2014).

Ham and colleagues in the same line among other ICT integration levels consider essential curricular integration and pedagogical integration. Curricular integration - is the degree and ways in which an ICT movement relates specifically to suitable educational module objectives and the same or complementary educational programs substance or abilities as other learning exercises in a given unit of work or arrangement of lessons. Pedagogical integration-is the degree to which the choice of specific ICT and how they are utilized in classes are reliable with and between the academic rationalities, introductions, and eagerly of the instructor and the learning styles, capacities, and inspirations of the understudies (V. Ham et al., 2002).

From a European perspective, digital competence has been used in different areas to describe competencies needed in a digitalized knowledge society. Digital competence includes students' ability to use technology in order to consume and access information. Moreover, digital competence also includes how students use technology to process, acquire, and evaluate gathered information. Finally, digital competence means that students can produce and communicate information with digital tools or media (Hatlevik, O.E. \& Christophersen, K.A., 2013).

Given such growth, virtual education systems have created new opportunities to follow trends and meet the students' and scholars' demands in the educational environment (M. Amorin\& F. Meirelles, 2018). As digital technologies are becoming a central part of the everyday work, teachers are forced to rethink and transform previous educational traditions by means of technology.

Teachers are always challenged teaching with technology as new technologies are presented regularly. Thus there is a need to continuously catch up with the new trends and new developments of technology, as most of the technologies under consideration in current literature are newer and digital, and have some inherent properties that make applying them in straightforward ways difficult (Koehler, M. J., Mishra, P., \& Cain, W. , 2013). Koehler and his colleagues consider that at the heart of good teaching with technology are three core components: content, pedagogy, and technology, as well as the relationships among and between them. The interactions between and among content, pedagogy, and technology, produces the educational technology integration along with what Koehler at al. consider technology, pedagogy, and content knowledge (TPACK) framework (Koehler, M. J., Mishra, P., \& Cain, W. , 2013). It is probably no coincidence that pedagogical theories focused on digital tools have received so much attention in a time when high-tech tools impact everything, from everyday interactions to global relations (From, 2017).

In his book "Stratosphere: Integrating Technology, Pedagogy, and Change Knowledge" Fullan (2013) suggests four criteria that contemporary teaching and learning must meet: Eagerness for engagement from students and teacher, willingness to adapt, easy access to technology $24 \backslash 7$, and a problem solving approach (Fullan, 2013). In order to utilize digital technologies in pedagogy and learning, individual teachers must incorporate technology into their practice (Blundell, C., Lee, K. T., \& Nykvist, S. , 2015).

Teachers need to master more than the subject matter they teach; they must also have a deep understanding of the manner in which the subject matter (or the kinds of representations that can be constructed) can be changed by the application of particular technologies. Teachers need to understand which specific technologies are best suited for addressing subject-matter learning in their domains and how the content dictates or perhaps even changes the technology and vice versa (Koehler, M. J., Mishra, P., \& Cain, W. , 2013).

Our understanding of the classroom as a site for learning must be expanded through the increased use of digital media, both inside and outside of schools. The changing role of media in our societies, and especially the impact of digital technologies since the mid-1990s, has implications for where and how learning might happen, whether online or offline, situated or distributed (Erstad, 2014).

Integrating digital technologies in schooling and activating digital learning must occur in and through teacher practice within a specific educational context (Blundell, C., Lee, K. T., \& Nykvist, S. , 2015). 
The importance of educating the digital generation is not so much about being able to use digital media in and out of school, than it is about creating a space for reflection and the building of knowledge that will help all students participate as citizens in a digital culture (Erstad, 2015). Young people are very techsavvy and their minds work better with it, thus teachers should consider technology to be part of their syllabus (Beka A. , 2019).

Students are highly literate in the use of technology. They may be technology gurus (Valenza, 2007). Different scholars call today's generation with different "tech" names, i.e. "Digital natives", or "Net Generation" (Kennedy, G., Judd, T., Dalgarno, B. and Waycott, J., 2010). Marc Presnky called the today's generation as "Digital Natives".

Presnky (2001) states that: “Today's students, from kindergarten through college, represent the first generations to grow up with this new technology. They are all "native speakers" of the digital language of computers, video games and the internet" (Prensky, 2001).

Kosovo has incorporated the importance of the ICT integration in all the relevant education documents and legislation (Beka A. , 2014). Kosovo Curriculum Framework (KCF) of the Pre-University Education encapsulates its national mission to develop "knowledge society" (MEST, 2011). KCF is a competency based curriculum and within the Competency in communication and expression, it emphasizes that pupils should: "Follow general rules of: communication/interaction and be creative at the same time; use information and communication technologies (ICTs) programmes during their learning process and their school assignments; use ICTs and media effectively and responsibly as an important means of information, communication and interaction in the digital age". (MEST, 2011).

In developing the Competency in learning according to the KCF and becoming the "Successful learner", pupils are required to demonstrate functional literacy in, ICTs (among other skills) in everyday situations as well as the ability to earn by using ICTs, (MEST, 2011).

Through the Ministry of Education and its partners, there have been efforts to enhance the usage of technologies in teaching and learning. Developing ICT competencies for on service and pre- service teachers has been set as a goal in education strategies of MEST (Beka, A. \& Gllareva, D., 2016). More efforts have been made in improving the legislation and education policies, than in teachers' professional development, school digital equipment or creation of online teaching platforms that would help schools for online learning.

The most sensitive part of the implementation of the curriculum is the use of ICT. Teachers should be prepared to use the benefits of technology, thus enabling students to use the digital platforms for their professional development (Beka, A. \& Gllareva, D., 2016).

Teacher ICT competences are considered as one the key competences for the pre-service and inservice teacher in Kosovo (Beka A. , 2015). Students are more open to learning and researching. They are willing to spend more time working because they are very familiar with technology and their mindset works best when technology is an integral part of their work (Beka A. ,2019).

The situation with the COVID-19 Pandemic which led to school closure created a challenging situation. Schools had to shift from regular to online/virtual learning in if a very fast pace. Fast move toward online learning exposed teachers' lack of experience on how to use technology in their teaching practice (Orlando, J., \& Attard, C., 2016) and showed that teachers are not experts in teacher integration (Wake, D. \& Whittingham, J., 2013). In order to support student online learning teachers need long term practices with technology enabling them to make lasting changes in technology use (Kopcha, 2012). While most of them had a general knowledge of ICT, almost none of them had a pedagogical experience of ICT usage or with online classes. Without previous opportunity to use ICT pedagogically, teachers can't develop students' digital skills (Valtonen, T. et al., 2017).

Secondly, professors had to apply in online learning the syllabi's that were prepared for classroom -face to face- instruction. This required changes to be made in the content, size and length of lessons. It requires changes in evaluation and assessment, too. Adaptation of classroom designed course to online teaching is challenging (Moorhouse, 2020).

This unplanned transformation happened so fast without proper preparations. The good side of this transformation is that students will see their teacher as: "flexible, creative, and developing new ways to teach old things." (Keren-Kolb, 2020).

\section{METHODS}

This research was conducted using the mixed methodology, collecting the data through online questionnaires and Zoom interviews. The purpose of this research was to gather opinions from school teachers and principals regarding online learning, its management, and the challenges they faced during this transformative time. 


\section{This research was developed based on the following research questions}

1. What challenges will teachers and school principals face during the transformation of the teaching process from the regular one (in the school) to the online one?

2. What were the steps taken by school principals and teachers to start online learning?

3. What were the steps taken by the central and local level to help teachers and students to maintain online learning?

4. How prepared have teachers been to start online learning?

5. How do teachers organize online learning with their students?

6. How willing are the parents of the students to cooperate with the teachers in order for online teaching and learning to be satisfactory?

The population in this research is composed of principals and teachers of public schools in Kosovo.

The selected sample was random, and included 68 public schools in the country.

Parts of the sample were 10 school principals and 102 teachers. School principals were interviewed and these interviews were conducted through the ZOOM program. Each interview lasted from 30-40 min. The interview was semi-structured through which the researcher managed to get the attitudes of the principals regarding the whole process of online teaching and learning.

A questionnaire, which was prepared through the Google form platform, was sent to teachers. The questionnaire was prepared according to the Likert scale and included nominal and ordinal measurements.

The selected sample was random, and included 68 public schools in the country.

The questionnaire was divided into 5 Sections. The first section included instructions for the respondents regarding the purpose of the research and the importance of their involvement in this process. This section also contained the demographic part for the data of the rescuers. Moreover, this part was intended to collect some of the teachers' demographic data in order to make comparisons between different categories in accordance with the new way of teaching (online learning).

The second section focused on teachers' prior experience with online teaching or conferences, in which case teachers had the opportunity to express their views on the professional preparation they had before deciding on the progress of online learning. The second section focused on teacher preparation for daily online learning. In this part, teachers had the opportunity to present their opinions and experiences that they encounter every day in the preparation of the daily lesson.

The third section focused on presenting teachers' experiences during the online lesson. The fourth section focused on how the teacher gives homework to students during the online learning period and how they are managed by teachers.

The fifth and final section focused on parental willingness to help teachers and students achieve online learning. Regarding the cooperation of the parents, the impressions were collected only by the teachers, relying on the practical experience of their students' parents.

\section{RESULTS}

A total of 102 teachers and 10 principals of various schools in the country participated in this research. Respondents were from the country's urban and rural schools. Majority of the respondents, $87.3 \%$ of teachers were female and $12.7 \%$ male, due to the fact that the majority of teachers in Kosovo are female. The age of the teachers involved in this research was from 20-60 years old. Obtaining age-related information from respondents was done in order to compare the categories of teachers who have been most challenged during this process. The following table presents the percentage of teachers by age. According to it, the largest percentage of teachers (31.4\%) belongs to the age group 26-30 years old.

Table 1. Division of teachers according to their age

\begin{tabular}{|l|l|l|l|l|l|l|l|l|}
\hline Age & $\mathbf{2 0 - 2 5}$ & $\mathbf{2 6 - 3 0}$ & $\mathbf{3 1 - 3 5}$ & $\mathbf{3 6 - 4 0}$ & $\mathbf{4 1 - 4 5}$ & $\mathbf{4 6 - 5 0}$ & $\mathbf{5 1 - 5 5}$ & $\mathbf{5 6 - 6 0}$ \\
\hline Percentage & $16.7 \%$ & $31.4 \%$ & $13.7 \%$ & $10.8 \%$ & $12.7 \%$ & $8.8 \%$ & $5.9 \%$ & $10.8 \%$ \\
\hline
\end{tabular}

Respondents' work experience in teaching has varied from 1 to 20 years. Their work experience has helped us to understand how the situation has been managed by them and which category has been more easily adapted to the online learning process. The following table presents the percentage of teachers based on their work experience. 
Table 2. Division of teachers according to their working experience

\begin{tabular}{|l|l|l|l|l|lll|}
\hline $\begin{array}{l}\text { Working } \\
\text { experience }\end{array}$ & $\mathbf{1 - 5}$ year & $\mathbf{6 - 1 0}$ year & $\begin{array}{l}\mathbf{1 1 - 1 5} \\
\text { year }\end{array}$ & $\begin{array}{l}\mathbf{1 6 - 2 0} \\
\text { year }\end{array}$ & $\begin{array}{l}\text { More than 20 } \\
\text { years }\end{array}$ & \\
\hline Percentage & $47.1 \%$ & $19.6 \%$ & $15.7 \%$ & $7.8 \%$ & $9.8 \%$ & \\
\hline
\end{tabular}

Regarding the previous teachers' experience for online teaching, we noticed a high percentage of teachers (65.7\%) have never had experience with online teaching. Almost one third of them, 31.4\%, have occasionally had the opportunity to be part of online learning, while only $2.9 \%$ of them have had continuous online learning experiences. Teachers who have had online learning experiences, whether continuous or occasional were mostly of younger age and have been a part of various international study programs. Being a part of various international study programs has given them the opportunity to be more familiar with online teaching and learning, although at the time they were students, and their responsibilities were different.

In the context of teachers' experience with the use of online platforms (Google Classroom, Google Meet, Zoom, etc.), it is noted that the largest percentage of them (57.8\%) have not had practice with any of these platforms. One third of them, 36.3\%, stated that their experiences with online platforms were rare; however these platforms have not been completely unknown to them. Only small percentages (5.9\%) have known these platforms well and have been able to use them with their students.

Low percentages of teachers, only $29.5 \%$ have had the opportunity to attend training on the use of online platforms. Mostly these trainings are provided by the schools in which they work. These schools are mainly from the capital, where the largest concentrations of schools are. At the same time school principals are more active in creating better conditions for teachers. This was confirmed during the interview, by the three school principals from the city of Prishtina (the capital). They stated that on their own initiative they have organized trainings for the teachers of their schools.

One of the statements of the principals regarding the training of teachers for the use of online platforms has been

“... the unexpected situation for the immediate school closing, due to pandemics, created many difficulties in our work. Some of the school principals have talked and agreed to take measures as soon as possible to help teachers at this point. Together with the other two principals, we decided to ask technology teachers to organize a training session for their colleagues, so that work would not be interrupted. Our good fortune was that ICT teachers, within our schools, showed willingness to organize these trainings even though they were not compensated financially ..." P3.

However, such initiative was not undertaken by school principals of other cities or villages of the country.

Online learning was not at all easy for teachers. This has been observed during their answers regarding the adaptation of curricula, teaching, online class management and other challenges that have been facing.

Research has shown that $54.9 \%$ of teachers felt stressed before class begins, while $44.1 \%$ of them do not feel stressed. A very small number of respondents, $1 \%$, couldn't determine whether they felt stressed or not.

The reason that teachers feel stressed is because they know that in addition to their students, parents or other family members may be part of the online lesson. The presence of the students' parents or other family members made the teachers insecure about teaching online. Another reason why teachers feel stressed is the fact that they can be recorded by their students or family and these videos can be posted online at various social networks. There were teachers who were not comfortable with their voice or their images appearing on the computer or phone screen. However, there were also teachers who did not have a specific space in their homes, in which other family members would not interrupt their online teaching.

Although there were various reasons for their insecurities when it comes to teaching online, about $58.8 \%$ of teachers teach 5 times a week (every working day). A dozen of them, $12.7 \%$ meet with their students only twice a week and for the remainder of the week they communicate through Google Classroom. Another, $10.8 \%$ of respondents teach 3 times a week, while $9.8 \%$ of respondents teach only once a week and finally $7.8 \%$ of respondents teach 4 times a week.

One of the issues that preoccupied teachers the most was that they had difficulty organizing the online class, since they did not have direct supervision over their students. The majority of the respondents, $75.5 \%$ said that the inability to observe students directly was a big challenge for them. One forth of respondents $24.5 \%$ did not consider this factor a challenge because they were more prepared and had more experience in this regard. 
Respondents were concerned whether students understood the topic that was being discussed. The majority of the respondents, $60.8 \%$ constantly had this concern. In addition, more than one third of the respondents, $38.2 \%$ had this concern from time to time, depending on the topic they were dealing with. And a small number of respondents, only $1 \%$ did not have this concern at all.

Another concern for teachers during online teaching was whether their students were paying full attention during the class. This uncertainty was always felt by $54.9 \%$ of teachers, while $35.3 \%$ of teachers felt this uncertainty from time to time, and $9.8 \%$ of teachers didn't think that such a thing would be possible because students were trying to be as attractive as possible during their online teaching.

Homework assignments for students were another challenge teachers faced. A large majority of the teachers (95.1\%) constantly gave assignments to students, while only $4.9 \%$ of them never gave homework assignments to their students.

Some of the teachers preferred assigning projects to the students more and these projects were done by the students in collaboration with other students. this way teachers reduced the number of assignments they had to assess and evaluate and it was easier to manage.

Regarding homework assignment, teachers have also asked for parental cooperation so that parents can supervise their children while they are doing homework. In this regard, parents have shown willingness to cooperate with teachers. Majority of the teacher respondents, $74.5 \%$, fully agree that parents had shown willingness to cooperate. Less than a quarter of the respondents, $23.5 \%$ partially agreed, while only $2 \%$ of respondents did not agree that parents had shown willingness to cooperate with them at all.

Teachers have confirmed that parents, in addition to accompanying their children with the online learning, organize additional activities in order to make learning more attractive to children and so that children comprehend as much as possible from the topics. This was confirmed by $84.3 \%$ of the teacher respondents. A small number of respondents, 7.8\% think that parents never organize any additional activities and a similar number, $7.8 \%$ of respondents have stated that they do not have such information from parents.

School principals, on the other hand, faced difficulties of a different nature. it was a priority for them to start online learning after school. During the interview, they said that this was not an easy process because they never thought that their schools would teach online. It was a difficult and almost impossible process for them. One of the directors said that despite the fact that discussions had started to initiate online learning, they did not believe that such a thing would work. He stated:

"... now when I think about the beginning of this process it really seems incredible how we managed to mobilize in such a short time to accomplish such a serious job, however I am very happy that despite the difficulties, we managed to make our online classes functional ..."P1. Another principal said, "Despite the alarming situation, we did not think long and hard about how online learning would work, we had no idea what was waiting for us and how we would start this process. Regardless of all the challenges, as much as we had the opportunity to intervene, I think we succeeded. But also the merit for starting this process, even with its difficulties, belongs to teachers and parents. I have never seen such a willingness to cooperate as much as throughout this period, especially from my parents ..."P2.

However, the situation seemed to be different in rural schools. The principals of these schools stated that:

"... online learning in our country is almost impossible, because pupils initially lack electronic equipment and internet access at home. How could I ask our pupils' parents to do this when I knew their living conditions were difficult? I am very happy that the Ministry of Education has intervened quickly and enabled children to learn remotely, through TV broadcasting which they have prepared for the teaching units; otherwise I am convinced that the children in our surroundings would have been left without lessons... "P10. Other school principals in rural areas had similar views. One of them said:"I had asked our pupils' parents to propose any form of communication in order to help our students. Some of them had social network (Facebook) accounts, so we started to use these social networks for online learning. I am aware that this was not very professional, but we used available opportunities..." P9.

Another challenge that principals addressed was the mobilization of teachers and the mobilization of parents. Teacher mobilization was challenging because a number of them were not at all prepared for online learning. A director from the city of Prizren said:

"I had no idea how we should start with this way of teaching. To be honest my school has teachers who are older and it's not like they have information about the use of technology. .... I have the same challenge, I belong to the older generation and we have not had the opportunity to keep pace with technological developments.... I understand the teachers, so I was very worried. As for our pupils' parents, I was not worried because most of them are younger and have experience in using technology ..."P5. 
In the capital, the situation was more favorable, according to the statements of school principals in Prishtina. Teachers' mobilization in response to the new situation was rapid.

"We were so willing to continue with online learning. Perhaps since most of the teachers are younger. What we saw from them was a willingness not only to continue with online learning but my school's teachers were willing to help their colleagues ...which to tell you the truth, I did not expect from them. Parents have also been very cooperative. Our pupils meet with their teachers every day; this has helped the students to overcome this stage much more easily. We have received various videos from parents, in which different activities that the children have done together with them have been presented. Indeed it was worth the struggle. I'm very happy "P3.

The role of the Ministry of Education and Municipal Education Directorates, of course, has been very important during this process. According to the directors, although the efforts of these institutions were evident, they did not act quickly.

"... We had started online learning while the MEST talked about guidelines, regulations or decisions that will be taken regarding online learning. As always, these institutions have not been quick to manage situations. After almost a month of teaching, MEST created TV shows with school content. These shows are very insufficient because for each subject a 10-minute recording was made, which included an explanation, an example related to the lesson and clarification of homework ... Imagine all this had to be understood in ten minutes by a first, second, third grade pupil... in my opinion this has been very insufficient. Honestly, it was difficult to understand, even for adults let alone for children, not to mention the content errors that these recordings had ..."P7.

In addition, Director P4 stated that:

"The Ministry of Education again failed to act on time ... they continue to be an institution that prepares educational policies and to serve us for implementation. It is time for changes not only to be made from the top- down, but also to be made upside down. This period has best proved who the fastest and most efficient in planning and implementation people were. I am not talking about the quality of teaching and learning because that part wants new research after a period, but I am talking about the mobilization of teachers, parents and the community ... the Ministry must understand that without the involvement at the implementation of educational policies from the lowest level to the highest, achievements that the education system of Kosovo should have will continue to remain only in the minimum ...."P4.

\section{DISCUSSION AND CONCLUSIONS}

The results of the research show that the beginning of the online learning process has been challenging for everyone including: school principals, teachers, parents and most of all for pupils. The education system in Kosovo has never prioritized investment in technological equipment, and teachers' continuous professional development in the field of technology. The COVID-19 pandemic shook the education system in Kosovo and influenced education institutions to take online learning seriously for the first time, including pre-university and university levels. For decades, the education system in Kosovo failed to go beyond the planning stage, when it comes to the need for digitalizing the education system in the country (MEST, 2016). Throughout this time, the digitalization of the education system has been on the list of priorities, but it has never been taken seriously.

The mobilization of schools proved to be faster than the mobilization of the Ministry of Education or Municipal Education Directorates. This situation highlighted that school principals were very willing to take concrete measures to start online learning. They managed to mobilize teachers to start online learning. They faced successive challenges such as: defining the online platforms to be used, mobilizing parents, organizing training within the school by the teachers themselves and overcoming the challenges of the teachers who have never taught online.

Teachers were very challenged during this pandemic period. Although their workload has tripled, they still insisted on contributing as much as possible to online learning. A number of them faced a lack of competence when it comes to using technologies and online platforms. Online learning also compelled them to restructure their curricula and adapt it to the new form of learning. It was also challenging to hold classes with pupils. To engage them, try to be creative, and so on. Teachers were also assisted from local and international institutions or even civil society organizations, giving them the opportunity to participate in various workshops, where the topics related to the learning process were addressed.

Parents, although in some cases very deprived of technological means, still did their best to cooperate with teachers and help children. Together with the teachers, they managed to develop additional activities for their children and help them to easily overcome the challenges of learning online. 
From the results of the research and their discussions, the conclusion is that the role of schools is crucial in society. Education institutions can connect teachers, parents, the community and other relevant institutions to help the operation and transformation of the education system in the country and the whole society.

This correlation enables all pupils and students to participate comprehensively in the education system, allowing each of them to have the opportunity of an education and development.

The pandemic period, in addition to the difficulties, inspired good things to our society. It showed the need to think seriously about investments in the digitalization of the education. Central and local institutions have realized that this process is not impossible, thus they cannot use the excuses that this process is too difficult to carry out. The use of digital technologies in educational environments enables students to expand their knowledge, skills and their possibility of inclusion.

\section{REFERENCES}

Amorin, Marcelo \& Meirelles, Fernando. (2018). Influence of Digital Transformation on Teaching Practices. Twenty-fourth Americas Conference on Information Systems. New Orleans,.

B.Beka \& A. Beka. (2017). The lack of Electronic Thesis and Dissertations (ETD) database and its impact to doing research in Kosovo's Universities. DisCo 2017 Open Education as a way to knowledge society (pp. 410-419). Prague: Center for Higher Education Studies. Retrieved from http://disconference.eu/wp-content/uploads/2017/01/DisCo-2017-Open-education-as-a-wayto-a-knowledge-society_-12th-conference-reader.pdf

Bandura, A. (2001). Social Cognitive Theory of Mass Communication,. Media Psychology, 3:3, 265-299. doi:10.1207/S1532785XMEP0303_03

Beka, A. \& Gllareva, D. (2016). The importance of using electronic portfolios in teachers work. Applied Technologies and Innovations, 32-42. doi:http://dx.doi.org/10.15208/ati.2016.01

Beka, A. (2014). Social networks as significant factor in the professional development of young people in Kosovo. Perspectives of Innovations, Economics and Business, 14 (3), 147-151. Retrieved from RePEc:pdc:jrpieb:v:14:y:2014:i:3:p:147-151

Beka, A. (2015). Sustainability in higher education: Linking teacher education with labor market in Kosovo. In J. P. Davim, Challenges in higher education for sustainability (pp. 189- 199). Springer.

Beka, A. (2019). Collaborative learning among students - increasing student learning for a sustainable future. In J. e. al. (Ed.), Disco 2019 E-learning: Unlocking the Gate to Education around the Globe (pp. 357-369). Prague: Center for Higher Education Studies. doi:https://dspace.uzhnu.edu.ua/jspui/bitstream/lib/31652/1/DisCo-2019-_E-learning-_Unlocking-the-Gate-of-Education-around-the-Globe_14conference-reader-1.pdf

Blundell, Christopher, Lee, Kar-Tin, \& Nykvist, Shaun. (2015). Conceptualising the challenge of integrating digital technologies in pedagogy. In G. \&. In Finger, Educators on the edge: Big ideas for change and innovation. (pp. 44-51). Australian College of Educators (ACE), A. Retrieved from https://eprints.qut.edu.au/90567/

Ch. N. Blundell, K. Lee, Sh.Nykvist. (2016). Digital Learning in Schools: Conceptualizing the Challenges and Influences on Teacher Practice. Journal of Information Technology Education: Research Volume 15, 535-560. doi:10.28945/3578

Erstad, 0. (2014). The Expanded Classroom spatial relations in classroom. Nordic Journal of Digital $\begin{array}{lllll}\text { Literacy } & \text { vol. } & 9, & N r . & 1,\end{array}$ doi:https://www.idunn.no/file/pdf/65829169/the_expanded_classroom__spatial_relations_in_classroom_pra.pdf

Erstad, 0. (2015). Educating the Digital Generation - Exploring Media Literacy for the 21st Century. Nordic Journal of Digital Literacy 4, 85-102.

From, J. (2017). Pedagogical Digital Competence-Between Values, Knowledge and Skills. Higher Education Studies; Vol. 7, No. 2, 43-50. doi:10.5539/hes.v7n2p43

Fullan, M. (2013). Stratosphere: Integrating Technology, Pedagogy, and Change Knowledge. Pearson.

Hatlevik, O.E. \& Christophersen, K.A. (2013). Digital competence at the beginning of upper secondary school: Identifying factors explaining digital inclusion. Computers \& Education, 63(1), 240-247. E. Retrieved from www.learntechlib.org/p/132296

Kennedy, G., Judd, T., Dalgarno, B. and Waycott, J. (2010). Beyond natives and immigrants: exploring types of net generation students. Journal of Computer Assisted Learning, 26, 332-343. Retrieved from https://doi.org/10.1111/j.1365-2729.2010.00371.x 
Keren-Kolb, E. (2020). Liz Kolb interview highlights changes in education during the coronavirus outbreak. (J. Tolley, Interviewer) Retrieved from https://soe.umich.edu/news/liz-kolbinterview-highlights-changes-education-during-coronavirus-outbreak

Koehler, M. J., Mishra, P., \& Cain, W. . (2013). What is Technological Pedagogical Content Knowledge (TPACK)? Journal of 13-19. doi:https://doi.org/10.1177/002205741319300303

Koehler, M. J., Mishra, P., \& Cain, W. (2013). What is Technological Pedagogical Content Knowledge (TPACK)? Journal of Education, 193(3), 13-19. doi:10.1177/002205741319300303

Kopcha, T. J. (2012). Teachers' perceptions of the barriers to technology integration and practices with technology under situated professional development. Computers \& Education, 59(4), 1109-1121. doi:10.1016/j.compedu.2012.05.014

M. Amorin\& F. Meirelles. (2018). Influence of Digital Transformation on Teaching Practices. Twentyfourth Americas Conference on Information Systems (p. 7). New Orleans,: Association for Information Systems. doi:https://aisel.aisnet.org/amcis2018/Education/Presentations/7/

M. Douse and Ph. Uys. (2020). One world one school: Education's forthcoming fundamental transformation. Online self published: Online self published. Retrieved from http://www.globeonline.com/oneworldoneschool.pdf

M. Fullan and K. Donnelly. (2013). Alive in the Swamp: assessing digital innovations in education. London: NESTA. Retrieved from https://media.nesta.org.uk/documents/alive_in_the_swamp.pdf

M. Lahovik and L. Breznik. (2013). Innovation Management and Technological Capabilities as a Source of Competitive Advantage. Managements, Knowledge and Learning International Conference, (pp. 772-777). Zadar.

MEST. (2011, August). http://www.ibe.unesco.org. Retrieved May 13, 2020, from http://www.ibe.unesco.org://www.ibe.unesco.org/fileadmin/user_upload/archive/curricula/ko sovo/kv_alfw_2011_eng.pdf

MEST. (2016, July 2). https://masht.rks-gov.net/uploads/2017/02/20161006-kesp-2017-2021-1.pdf. Retrieved from https://masht.rks-gov.net/uploads/2017/02/20161006-kesp-2017-2021-1.pdf: https://masht.rks-gov.net/uploads/2017/02/20161006-kesp-2017-2021-1.pdf

Moorhouse, B. L. (2020). Adaptations to a face-to-face initial teacher education course 'forced' online due to the COVID-19 pandemic. Journal of Education for Teaching, 1-4. doi:10.1080/02607476.2020.1755205

OECD. (2019). OECD Skills Outlook 2019: Thriving in a Digital World. Paris: OECD Publishings. doi:doi.org/10.1787/df80bc12-en.

Orlando, J. (2014). Teachers' changing practices with information and communication technologies: an up-close, longitudinal analysis. Research in Learning Technology, 22, 20-35. doi:10.3402/rlt.v22.21354

Orlando, J., \& Attard, C. (2016). ). Digital natives come of age: the reality of today's early career teachers using mobile devices to teach mathematics. Mathematics Education Research Journal, 28(1),, 107121. doi:10.1007/s13394-015-0159-6

Pettersson, F. (2018). On the issues of digital competence in educational contexts - a review of literature. Education and Information Technologies volumel 23, 1005-1021. doi:10.1007/s10639-017-96493

Prensky, M. (2001). PrensDigital Natives, Digital Immigrants Part 1. On the Horizon, Vol. 9 No. 5, 1-6. doi:10.1108/10748120110424816

Prensky, M. (2016). Education to Better Their World. Teachers College Press .

Tallvid, M. (2016). Understanding teachers' reluctance to the pedagogical use of ICT in the 1:1 classroom. Education and Information Technologies volume 21, 503-519. doi:10.1007/s10639-014-9335-7

V. Ham et al. (2002). What Makes for Effective Teacher Professional Development in ICT. Ministry of Education, New Zealand. Christ Church: Ministry of Education, New Zealand. Retrieved from http://citeseerx.ist.psu.edu/viewdoc/download?doi=10.1.1.618.1452\&rep=rep1\&type=pdf

V. Ham, A.Gilmore, A. Kachelhoffer, D. Morrow, P. Moeau and D. Wenmoth. (2002). What Makes for Effective Teacher Professional Development in ICT. Christ Church: Ministry of Education, New Zealand.

Valenza, J. (2007). They might be gurus. In D. L. E. Rosenfeld, Toward a 21st-Century School Library Media Program (pp. 226-234). Scarecrow Press (October 15, 2007).

Välimaa J., Papatsiba V., Hoffman D.M. (2016). Higher Education in Networked Knowledge Societies. In V. J. Hoffman D., RE-BECOMING UNIVERSITIES?. The Changing Academy - The Changing Academic Profession in International Comparative Perspective, (p. Chapter 2). Springer. doi:10.1007/97894-017-7369-0_2 
Valtonen, T. et al. (2017). TPACK updated to measure pre-service teachers' twenty-first century skills. . Australasian Journal of Educational Technology, 33(3), 2-17. doi:10.14742/ajet.3518

Wake, D. \& Whittingham, J. (2013). Teacher Candidates' Perceptions of Technology Supported Literacy Practices. Contemporary Issues in Technology and Teacher Education, 13(3),, 175-206. Retrieved from https://www.learntechlib.org/primary/p/42101/

Wan, Y. S. (2020). Education during COVID-19. Institute for Democracy and Economic Affairs 19. Retrieved from https://www.researchgate.net/publication/340860261_Education_during_COVID-19 